\title{
ANNIKA OLSSON
}

\section{GROTESKA KROPPAR I FOLKHEMMETS SVERIGE}

\section{PUSS - opassande estetik och retorik 1968-1974}

\author{
Humor är en ickevåldsmetod och effektivt. Människor med \\ makt tycker inte om att bli skrattade àt. ${ }^{1}$
}

Gloria Steinem

Den här artikeln vill genom en analys av satirtidskriften PUSS (1968-1974) diskutera det som uppfattas som problematiska och opassande uttryck i offentliga samtal och rum. ${ }^{2}$ Hur ska vi förstå och förhålla oss till bilder och texter som kränker, kliver över gränser, provocerar och stör ordningen? Och på vilket sätt präglas det som uppfattas som opassande av kroppar och kroppslighet? Artikeln kretsar kring den grundläggande frågan om opassande bilder och uttalanden i offentligheten fyller någon funktion eller om de bara är att beteckna som "smuts" som ska städas bort? ?3 Utgångspunkten är den komplexa situation som tidigare forskning återkommer till: att politisk satir som rent faktiskt kan vara ett problem, samtidigt har flera positiva funktioner för både individer och samhällen. ${ }^{4}$ Robert Darntons klassiska studie Pornografi och revolution (1996) har ju också lärt oss att det finns mer än ett skäl att studera det som samhällen upplever som just smuts: ${ }^{5}$ "Mening blir till på gatunivå lika väl som i böckerna”, som han uttrycker det. ${ }^{6}$

Men jag vill också argumentera för att PUSS har något specifikt att säga oss om kroppens plats i det svenska offentliga samtalet och i folkhemmet vid tiden för dess utgivning när det gamla "Lort-Sverige" var tillsynes bortstädat av socialdemokratins sociala ingenjörskonst, ${ }^{7}$ och det i många stycken ultra-moderna svenska välfärdssamhället växte fram genom miljonprogram, jämställdhets- och sexualpolitik, utbildningspolitik, biståndspolitik och kulturpolitik. ${ }^{8}$ PUSS är en produkt som lämpar sig väl för denna typ av reflektion eftersom den, för att tala med Lars Norén, tydligt sitter "som en termometer/ i världens röv". ${ }^{9}$

Tidskriften PUSS startades och drevs av konstnären Lars Hillersberg tillsammans med en grupp andra konstnärer och författare, och sade sig producera en satirisk anti-propaganda som skulle störa ordningen. "Vi vill vara 
obekväma och otrevliga” lyder programförklaringen i det inledande numret, som tidskriften måste sägas leva upp till. ${ }^{10}$ Den orsakade skandal inte enbart inom konstvärlden utan i offentligheten i stort med både åtal och uteslutningar ur ordinarie distributionskedjor som följd. ${ }^{11}$ PUSS åstadkom detta inte främst genom att vara politiskt obekväm utan genom att arbeta med en estetik och konstnärlig form som uppfattades som stötande och opassande och där tecknade serier och groteska kroppar spelar en central funktion. ${ }^{12}$ Som Pelle Anderssons förord till en antologi om Hillersberg påminner oss om: "Satir är det osmakligas konst". ${ }^{13}$

Mot denna bakgrund fokuserar min läsning av PUSS vad det är för ordning som störs och hur PUSS går tillväga rent konkret: vilken retorik och estetik används? Artikeln är baserad på en genomgång av alla nummer och en retorisk läsning av text och bild. ${ }^{14}$ Metodologiskt är artikeln en klassisk representations-analys, ${ }^{15}$ och den teoretiska begreppsram jag valt att arbeta med är den groteska realismens. ${ }^{16}$ Här delar jag Anna Lundbergs, Sara Cohen Chabots och Joe Thorogoods tankar kring att Michail Bachtins teorier kring det karnevaliska och det groteska hjälper oss att förstå och resonera kring den humor som gör oss ambivalenta, som både roar och oroar på samma gång. ${ }^{17}$ Detta eftersom den groteska kroppen förankrar oss i köttet och det ambivalenta; den överskrider gränser och ifrågasätter normer. ${ }^{18}$

\section{PUSS i den könade folkhemspolitiken}

PUSS är med andra ord en omdiskuterad tidskrift som på en och samma gång är extremt estetiskt och politiskt medveten och förvånansvärt konventionell och vulgär. Tidskriften aktualiserar frågor som berör satirens och antipropagandans relation till dominerande samhällsdiskurser och propaganda rent allmänt, men också dess relation till hatpropaganda och stereotypa rasistiska, sexistiska och homofoba representationer. ${ }^{19}$ Här befinner sig tidskriften inom samma spektrum som den idag omdiskuterade satiren i Jyllands-Posten eller Charlie Hebdo. Det är också just denna komplexitet och de ambivalenta känslor som denna typ av satir väcker som gör den intressant och relevant att analysera och diskutera. ${ }^{20}$

Åke Holmqvist (som själv ingick i redaktionen) kallar PUSS en vänstertidskrift "med stake", ${ }^{21}$ medan Lars Bang Larsen talar om en undergroundtidning som arbetade med "politisk porno", ${ }^{22}$ och Kjell Östberg utnämner den till "den mest rabulistiska av alla 6o-talets publikationer" ${ }^{23}$ Den startade som veckotidning, kom ut ett par gånger i månaden efter nummer 3 och tappade farten något efter det inledande året. Huvuddelen av de 24 numren trycktes i A4-format (I-2I), de sista tre numren som tabloid. Utgivningstakten varierade. Upplagan nådde som mest Io ooo exemplar och nådde sina läsare genom prenumeration och lösnummersförsäljning enligt den lockande devisen: "Köp Puss, familjesnusk till husbehov, barnens och småfåglarnas vän”. ${ }^{24}$

Holmqvist berättar att förarbetet med tidskriften inleddes 1967 när Hillersberg hade tilldelats Ester Lindahls tvååriga stipendium: "Nu hade han både den ekonomiska och ideologiska makten och vi andra hade bara att - mer eller mindre - hänga med i svängarna” ${ }^{25}$ Här framgår också att PUSS lanserades genom två olika utställningar som gjorde skandal och banade väg för tidskriften. ${ }^{26}$ I redaktionen sägs enligt tidskriften själv ingå Leif Katz, Lena Svedberg, Åke Holmqvist, Karl-Erik Liljeros, Carl Johan De Geer, Ulf Rahmberg, Karin Frostensson, Christer Themptander och Arne Svensson. Utöver dessa så medverkar även en stor mängd andra namnkunniga svenska författare, skribenter och konstnärer som Sonja Åkesson, Öyvind Fahlström, Lars Forssell, Gunnar Ohrlander, Lars Norén, Staffan Beckman, Marie-Louise De Geer, Jan Hannertz, Einar Heckscher, Carl Fredrik Reuterswärd och Anette Kullenberg. Som Andreas Berg konstaterar, enbart i de tio nummer som utkommer under 1968 återfinns signerade bidrag av över 
50 personer och till dessa kommer bidrag som saknar signatur. ${ }^{27}$ Enligt Valdemar Gerdin var det över Ioo personer som bidrog till PUSS under de år den kom ut, men kärntruppen utgjordes av Lars Hillersberg, Karin Frostenson, Lena Svedberg, Ulf Rahmberg och Carl-Johan De Geer. ${ }^{28}$

Att PUSS nedläggning 1974 inte skedde obemärkt, utan med utställning på Konstakademin och med tal av Ulf Linde är talande för dess position i det samtida konstnärliga rummet. ${ }^{29}$ Mot denna bakgund är det också logiskt att Hjärtat sitter till vänster, den stora utställningen med fokus på svensk konst 1964-1974, citerar kritikern Torsten Ekbom som i en artikel $i$ Dagens Nyheter 1968 kallat PUSS för "den i alla läger så välsedda skandaltidskriften". ${ }^{30}$

Det innebär alltså att PUSS kommer ur och verkar inom en sfär befolkad av konstnärer och intellektuella, och att den tar en rejäl plats i det svenska offentliga samtalet och rummet genom att säljas på gatan, genom prenumerationer och genom att väcka indignerad debatt, bli omskriven i andra media och bli stämd. ${ }^{31}$ Som Berg uttrycker det: "Redaktionen ansträngde sig till sitt yttersta för att utmana anständighet och god smak". ${ }^{32}$ Detta projekt genomförs tidsmässigt mitt under den period som i Sverige domineras av, inte bara demonstrationer och strejker, geopolitisk turbulens, kallt krig, Vietnamkrig och sexuell frigörelse, utan också den svenska folkhemspolitiken och en kritisk diskussion av vad den innebar, där inte minst intellektuella spelade en aktiv roll. ${ }^{33}$ Kjell Östberg formulerar det på följande vis: "Inte förvånande var det socialdemokratin som hamnade i skottgluggen i den debatt som allt mer intensivt fördes kring sprickorna i folkhemmet. Partiet hade ju innehaft regeringsmakten i ett tredjedels sekel. Från såväl höger som vänster ökade kritiken mot byråkrati och maktmissbruk". ${ }^{34}$

Yvonne Hirdman har i studien Att lägga livet tillrätta (1989) beskrivit just detta ordnande som den övergripande målsättningen med folkhemspolitiken. Detta innebar rent konkret att alla samhällsproblem sågs som möjliga att lösa genom en välfärdspolitik där människor på olika vis skulle fostras och knuffas i en eftersträvansvärd riktning. ${ }^{35}$ För att återvända till metaforen kring smuts och städning går det också att framställa det socialdemokratiska projektet "att lägga livet tillrätta" som ett städprojekt där de ting som hamnat på fel plats skulle sorteras, organiseras och ordnas; där det som var smuts skulle samlas ihop, sopas och skuras bort och den unkna luften vädras ut. Detta är centralt för att förstå inte bara vad tidskriften PUSS representerar utan också hur den agerar.

Jag läser alltså tidskriften som att det är den svenska folkhemspolitikens ambition att lägga livet tillrätta för alla medborgare och den centrala plats som kön har i denna politik, som PUSS siktar in sig på. I ett genusvetenskapligt perspektiv är det på ett vis självklart att just kön, kropp och sexualitet står i centrum för den som är ute efter att skapa förändring och ifrågasätta den dominerande politiska ordningen, men också för den som vill ta plats $\mathrm{i}$ det samtida konstnärliga samtalet. Detta mot bakgrund av den allmänna diskussion kring jämställdhet och sexualitet som fördes i det av socialdemokraterna dominerade Sverige vid denna tid, och där inte minst pornografin och den svenska synden nu bredde ut sig i offentliga rum samtidigt som Sverige också genomförde landets första sexualvaneundersökning (1967) ${ }^{36}$ Men också på grund av den funktion kön, kropp och sexualitet har inom den groteskt realistiska traditionen. ${ }^{37}$ Här inkluderar jag inte enbart det som Hirdman själv talar om (relationen mellan kvinnor och män i det hon betecknar som genussystemet ${ }^{38}$ ) utan kön i en vidare bemärkelse: kön i betydelsen kropp rent konkret, men också sexualitet och begär. ${ }^{39}$ PUSS är ju en vänstertidskrift med "stake" som rent bokstavligen låter nakna kroppar och blottade kön breda ut sig på tidningssidorna och i det offentliga rummet. ${ }^{40}$ Att det är kombinationen sex och politik som gjorde PUSS "explosiv" är också något som Leif Nylén 
konstaterar: "Puss romantiserade varken den sexuella revolutionen eller den politiska. Men man tog ett skamgrepp på politiken, drog ner byxorna på makthavarna och framställde dem inte bara symboliskt utan också bokstavligt som rövslickare eller rövknullare och skildrade gärna den ekonomiska utsugningen som sexuella övergrepp." ${ }^{41}$

\section{Grotesk realism, stötande estetik och retorik}

Betecknande för PUSS bildvärld, både den visuella och den textuella, är just att den materiellt-kroppsliga principen dominerar på ett vis som bryter mot den princip som inom retoriken kallas för decorum, och som reglerar vad som anses som socialt passande och respektabelt. ${ }^{42}$ Från dess första nummer till dess sista är PUSS fylld av bilder (både bokstavliga och metaforiska) som excellerar i och bejakar all typ av kroppslighet och inte minst delar eller praktiker som då ansågs opassande att visa eller tala om i det offentliga rummet och samtalet i Sverige, och som i viss mån fortfarande anses opassande, som genitalier och kroppsvätskor eller olika former av kroppskontakt, sex, sexuella begär (inte bara heterosexuella) och våld. Det är nakna tecknade eller fotograferade kroppar som har sex, som rör vid varandra, som blottar stora kukar, bröst och fittor, som sitter på toaletten, som slickar eller gapar stort, men det är också kroppar som blir misshandlade, fängslade, utsugna, trampade på. Det är inte enbart satiriskt berättande med tydlig förankring i sin samtid där aktuella politiska skeenden, personer, frågor tas upp utan också skrattkultur som arbetar i den groteskt realistiska traditionen som har den franske författaren Rabelais som en av de främsta företrädarna och förebilderna.

För att kunna förstå denna typ av skrattkultur och inte minst Rabelais, menar Michail Bachtin - vars verk Rabelais och skrattets historia (199I/1965) är standardverket för den som vill studera både skrattets historia och dess samtida praktik och uttryck - så måste man förstå att Rabelais "olitterära" och "stötande" bilder och berättande har sin grund i ett medvetet och explicit avståndstagande från det officiella; från kanon och det normativa: "Rabelais' bilder har en principiell och outplånlig 'icke-officiell' karaktär; ingen dogmatism, inget auktoritärt anspråk, inget ensidigt allvar kan bringas att harmoniera med Rabelais' bilder, ty dessa bilder är fientliga mot allt som är avslutat och stabilt, mot allt inskränkt allvar, mot alla färdiga lösningar vad gäller människans tankar och uppfattning om världen." 43

PUSS arbetar tydligt i Rabelais tradition genom att vara icke-officiell på alla sätt och vis. Den grundas och drivs av en enskild konstnär i samarbete med en grupp andra konstnärer, och saknar officiell sanktion genom att sakna ekonomiskt stöd av staten/makten (detta med att de inte tilldelas kulturstöd är för övrigt en återkommande trop) och är heller inte en kommersiell produkt. "Det fanns ingen affärsmässig kalkyl och inga skojfriska företag som backade upp PUSS. Ekonomiskt var det ett kamikazeprojekt" som Berg uttrycker det. ${ }^{44}$ Den arbetar med bilder - inte minst karikatyrer och den tecknade serien- som kan sägas vara fientliga mot det avslutade och stabila; allvar som inskränker och all slags dubbelmoral är dess fiende. Med Hillersbergs egna ord: "Vi arbetade ju själva i en sorts negativ anda; vi ville också vara med och rasera". ${ }^{45}$ Inte minst karikatyren, som är en återkommande figur i PUSS, är en bildform som väcker känslor och orsakar debatt. Den har betecknats som låg konst, problematisk, barnslig, omoralisk, fånig och farlig, och har också en ambition att vara just allt detta. ${ }^{46}$ Samma kan sägas om den tecknade serien som vid denna tid var kopplad till likartade föreställningar, vilket Kristina Alnerud Mejhammar förtjänstfullt redogör för i sin avhandling. ${ }^{47}$ Att den tecknade serien som genre inte enbart utmanar normer utan också bär på ett historiskt problematiskt arv och än idag väcker debatt kring sitt återkommande bruk av stereotyper är en annan viktig fråga. ${ }^{48}$ 
Det innebär att PUSS genom sin retorik och estetik driver gäck med den officiella maktens representanter. Politiker som statsministrarna Tage Ehrlander och Olof Palme, justitieminister Lennart Geijer, finansminister Gunnar Sträng, folkpartiledaren Sven Wéden, borgarrådet Hjalmar Mehr, är frekvent avbildade, liksom USA:s presidenter Lyndon B Johnson och Richard Nixon, och Egyptens president Gamal Abdel Nasser. Men även andra kategorier som polisen, kungahuset och storfinansen (Wallenberg) återfinns ofta. Utöver dessa ger sig PUSS också på helt andra grupper, ämnen och personer: till exempel de som PUSS uppfattar som rentänkande vänstermänniskor (Jan Myrdal) eller de som förstås som en slags moralismens överstepräster, särskilt om de berör droger eller sex. Dr Beijerot som likt Fantomen slåss mot knarket är en favorit, vilket har sin förklaring i det faktum att Nils Beijerot gått till historien som den svenska narkotikapolitikens fader men också tidigt uttryckt en högljudd kritik mot tecknade serier. ${ }^{49}$ Som Bang Larsen uttrycker det: " hela det politiska spektrat - inte bara de borgerliga, men också de röda, anarkisterna, bohemerna, fummarna - blev föremail för diskussion och hämningslösa karikatyrer. Något motsvarande är svårt att finna $i$ dag" ${ }^{50}$ I ett perspektiv går det att hävda att PUSS ger sig på allt och alla som i dagens debatt ofta betecknas som delar av etablissemanget och de olika dominerande samhällsnormer som de representerar. Bengt Olvång konstaterar i sin översikt av svensk konst: "Man var inte bara ironisk och provokativ i största allmänhet. Man var blasfemisk. Man hädade öppet Gud, regeringen och kungahuset." 51

\section{Materiellt-kroppslig retorik och estetik, hyperbol och degradering}

Förutom att PUSS tydligt har en "ickeofficiell” karaktär och tar avstånd från kanon och det normativa, vilket enligt Bachtin är grundläggande för den groteska realismen, så genomsyras också PUSS bildvärld av den groteska realismens andra faktorer: den materiellt-kroppsliga principen, hyperbolen och degraderingen. Det Bachtin kallar för livets materiellt-kroppsliga princip innebär att det kosmiska, det sociala och det kroppsliga hänger ihop och utgör en helhet som är något positivt. Det ger oss bilder där kroppen är i centrum, där någon äter eller dricker, men också bilder där människor har sex, eller med sexuell konnotation, eller där olika naturbehov uträttas, det vill säga allt det som enligt vedertagna officiella normer är avskilt och inte bör avbildas eller talas högt om enligt principen om decorum. Dessutom är bilderna präglade av hyperbolen - överdriften. ${ }^{52}$ Det ska flöda över, inte hålla sig inom gränser, vara "lagom" eller respektera normer. ${ }^{53} \mathrm{Jag}$ relaterar detta gränsöverskridande till den öppna kropp som Ingemar Haag menar är paradigmatisk för just den groteska bilden: "Att tränga in i ett 'utanför', eller att låta ett 'utanför' tränga in i oss - där har vi på många sätt paradigmet för den groteska bilden". ${ }^{54}$

Enligt Bachtin är den groteska realismens tydligaste karakteristika dock degraderingen: att allt som är upphöjt, oavsett om det är bokstavligen andligt och sägs tillhöra en annan sfär eller om det är världsliga höjder vi talar om, förs ned till det materiellt-kroppsliga planet. ${ }^{55} \mathrm{Sa}$ ker och människor tas ned på jorden, för att bli delaktiga i det kretslopp som pånyttföder; det är ett effektivt sätt att lösa upp gränser. ${ }^{56}$ Det innebär också att man förs ned och blir en del av "den lägre kroppens liv, magens och genitaliernas liv, och följaktligen akter som samlaget, avelsen, havandeskapet, nedkomsten, uppslukandet av föda, avföringen". ${ }^{57}$ Degraderingen kan också ses som ett dekonstruerande av vedertagna normer och privilegierade positioner och försanttaganden. ${ }^{58}$ Detta gäller också själva språket där bruket av det som Bachtin kallar för det "familjära språket på gator och torg" med invektiv, svordomar och obsceniteter blir centralt. ${ }^{59}$ Skymfande och nedsättande ord och ordspråk, som har sitt ursprung i ett magiskt besvärjande av gudarna, har enligt Bachtin 
förlorat sin magiska funktion och blivit ett ändamål i sig som bidrar till frihet och komik genom att bryta mot normer och vara hämtade från den icke-officiella sfären. ${ }^{60}$

Degradering, hyperbolen och den materiellt-kroppsliga principen genomsyrar PUSS. Själva titeln PUSS är ju en beskrivning av en kroppslig handling som involverar en eller flera kroppar, och möjligtvis också kroppsvätskor. En puss kan vara en del av ett dygdigt och högst respektabelt socialt mönster, som Nationalencyklopedin skriver "kyss med slutna läppar som uttr. för vänskap el. kärlek (vanl. dock utan inslag av erotik)", ${ }^{61}$ men det kan också vara uttryck för något erotiskt, gränsöverskridande, högst orespektabelt. PUSS första nummer signalerar detta genom ett omslag som pryds av den amerikanske presidenten Lyndon B Johnson, i rubriken betitlad "den deoderiserade amerikanske skunken" och med en påmålad knallröd pussmun på det svart-vita inramade ansiktsporträttet. Omslaget, signerat Hillersberg, signalerar att något stinker, och att det inte enbart har att göra med USA, utan med de respektabla praktiker som involverar en och annan kindpuss och parfymerade hycklande politiska relationer.

Om det inledande numret är tydligt, men också rätt förväntat i form av budskap och oförargligt i fråga om hur kroppen och det opassande används så kommer de följande numren att chocka det samtida Sverige rejält. I nummer tre från februari 1968 pryds omslaget av en tecknad bild av en naken kvinnokropp, signerad Karin Frostenson, där brösten, naveln och skötet är markerade av röda cirklar (eller badges) innehållande text. Den avbildade kvinnan poserar avslappnat i en traditionellt "sexig" pose där den högra handen vilar mot höften, medan den andra handen tycks vrida om den vänstra bröstvårtan/ en badge med texten "sex \& spekulation”. ${ }^{62}$ Det är dock inte denna bild utan ett par collage av högt uppsatta och respektabla politiska representanter som rör om i grytan rejält - för att degradering ska fungera effektivt underlättar det att kropparna är kända representanter för makten. I ett av dem syns den svenska statsministern Tage Erlanders huvud påklistrat ett foto av en man iklädd långkalsonger prydda av amerikanska flaggan, indikerande vems ärenden den svenska regeringen går eller helt enkelt indoktrineringen av Sverige. ${ }^{63}$ Detta tema är genomgripande och varieras på olika vis. ${ }^{64}$ Det som väcker mest uppmärksamhet i detta nummer och "gör präktig riksskandal" är dock bilden av en naken, vit man, endast iklädd svarta herrskor, som håller sin erigerade kuk i ett stadigt grepp med en tång och som har folkpartiledaren (och tångfabrikanten) Sven Wedéns huvud inklippt. ${ }^{65}$ Bilden är gjord av Hillersberg och lever upp till allt som omslagstexterna talar om: "vett \& villing, sex \& spekulationer, bluff \& båg”. ${ }^{66}$ Här kombineras på ett övertydligt vis degradering med överdriften och den materiellt kroppsliga principen.

Som en del av PUSS groteska realism fyller inte bara nakna kroppar, utan bilder osande av sexualitet med pornografiska referenser en viktig funktion. I skandalnumret med fokus på sex (nr 3) återfinns följaktligen fotografier där Carl-Johan och Marie-Louise De Geer ("gammal svensk adel") intar pornografiska poser. Bang Larsen uttrycker det som att pornografin tillskrevs samma subversiva potential som kritiskt medvetande, ${ }^{67}$ vilket inte var ovanligt vid denna tid där porren blev ett vapen i kampen för friare sexualitet, ökad individuell frihet och mot censur. ${ }^{68}$ Jag skulle vilja uttrycka det som att groteskt realistiska bilder kan degradera makten eller eliten genom bruket av pornografiska och skatologiska referenser just för att dessa ses som opassande och för att de bryter mot decorum, inte minst för hur makten och eliten (minns titeln på De Geers "porrbilder") ska representeras, men också för att de synliggör det mänskliga och det samhälleliga varat. Bachtin formulerar det på följande vis: "Nedsättandet gräver en kroppens grav för en ny födelse." 69 Det vill säga, det handlar inte enbart om att smutsa ned för att förgöra någon eller något, utan själva nedsmutsningen är endast en 
del i det kretslopp som livet består av. Som Joe Thorogood understryker: "Degradation does not refer solely to criticism, insults or satire of the highbrow culture or process, but also the enmeshing of the corporeal and the mind in a celebration of the cykle of life and death." ${ }^{\prime 0}$

Ett annat lysande exempel på hur detta kan komma till uttryck i PUSS är Lena Svedbergs kritiska bilder av den samtida "Konsumentkvinnan” där överdriften, det pornografiska och det skatologiska står i centrum. Här får läsaren följa "Nygifta Fru K i Skärholmen” i en bildsvit där en bokstavligen groteskt stor kvinna porträtteras sittande på toaletten med cigarett och flaska och i sällskap av en tv, tillfredsställande sina begär genom olika typer av droger, där inte minst massmediet fyller en central funktion som propagandaapparat och födande både "neurosedynvenus" och "fröken K” som "blev mamma upp i dagen". ${ }^{71}$ Även hennes serie "Folkhemmet" där ingen bryr sig om den lilla människan arbetar med denna effektiva estetik där den materiellt kroppsliga principen är rådande, ${ }^{72}$ liksom Svedbergs omslag till nummer 6 där dåvarande chefredaktören till Svenska Dagbladet torkar den amerikanske president Johnsson i röven med sin tidning. ${ }^{73}$

\section{Genrekontrakt, karnevaliska strömmar och negativ satir}

Som Rita Felski konstaterar i Uses of Literature (2008) har litteraturen många funktioner, och vi som läsare kan använda texter på olika vis. Vi kan upptäcka oss själva i dem, bli förflyttade till andra världar, få kunskap och bli omskakade. ${ }^{74}$ Mot bakgrund av PUSS groteskt realistiska estetik och retorik är det möjligt att som läsare upprätta ett genrekontrakt med tidskriften där PUSS är en plats där karnevalens logik härskar och där vi som läsare har möjlighet att få tillgång till alla de funktioner Felski talar om. ${ }^{75}$ Karnevalen utmärks ju av sin gränsöverskridande karaktär. Den är mellan konst och liv, ett liv som lek, och gör inte någon åtskillnad mellan aktör och åskådare. ${ }^{76}$ Den är också en befrielse, om än tillfällig, från den ordning som råder och den sanning som härskar. Medan de officiella festernas funktion, enligt Bachtin, var att sanktionera och befästa en rådande ordning, vilket också innebar att de enbart var bakåtblickande, var karnevalens funktion den motsatta; den var till för att förändra, förnya, ifrågasätta det fullbordade och avslutade: "Den såg in i den ofullbordade framtiden." 77

Detta möjliga genrekontrakt har med genrekunskap och erfarenhet att göra, som Johanna Doona konstaterar i en artikel om hur åskådare hanterar politisk satir. ${ }^{78}$ Att inte alla läsare knyter samma typ av kontrakt är ofrånkomligt. Vissa kom under den period PUSS gavs ut, och vissa kommer idag, att argumentera för en annan läsning och kanske uppfatta det som PUSS representerar, eller delar av det PUSS innehåller, som ren smuts i det svenska folkhemmet, något som borde och ska städas ut. Detta var också den reaktion som tidskriften var ute efter, och som lyftes fram som bevis på att deras störande varit framgångsrikt. Det går alltså att hävda att själva grundvalen för att en tidskrift som PUSS ska lyckas är just att majoriteten av läsarna, eller de läsare som representerar någon form av makt eller etablissemang, inte läser PUSS som ett uttryck för en klassisk skrattkultur, utan för det motsatta. Läsarterna och därmed funktionerna varierar. Som Felski understryker, är det också möjligt att en och samma läsare växlar mellan funktionerna i en och samma text : "I hold fast to the view that any account of why people read must operate on several different fronts, that we should relinquish, once and for all, the pursuit of a master concept, a key to all the mythologies." 79 Det vill säga, det är möjligt för oss att både få kunskap och bli chockade, eller blir roade och oroade, på samma gång.

Det finns dock en aspekt av det karnevaliska där jag menar att PUSS mer är ett uttryck för en samtida konstscen än en folklig karneval. När Bachtin talar om karnevalens skratt skiljer 
han mellan folkfestens skratt och det sätt på vilket skrattet används av dem han kallar för nyare tiders satiriker. Karnevalsskrattet är festens skratt och inte en individuell reaktion. Det tillhör hela folket och praktiseras av folket bland folket. Det är också universellt, riktat mot alla och allt, även mot satirikern själv. Dessutom är det tvetydigt, på samma gång glatt och sorgligt. Denna komplexitet saknas i det skratt som Bachtin betecknar som negativt. De satiriker som arbetar med detta skratt "placerar sig utanför det han driver gäck med, i opposition mot det och härigenom tillintetgörs totaliteten i den komiska aspekten av världen, det löjeaktiga (negativa) blir en partiell företeelse." ${ }^{80}$ Dessutom görs det till något som satirikern varken har ansvar för eller är delaktig i.

Här finns det en tydlig skillnad mellan folkfestens skratt och det skratt som produceras i och genom PUSS. Visst slår PUSS mot makten, men samtidigt är det tydligt en "underground"tidskrift som placerar sig i opposition mot och inte vill vara delaktig i eller ansvarig för det den framställer som löjeaktigt. PUSS redaktörer och övriga medverkande urskiljer sig genom att särskilja sig och skapar därigenom också en produkt som blir en konstnärlig plattform för dem själva att verka ifrån och genom. ${ }^{81}$ Som jag lyfte inledningsvis är det betecknande att PUSS går i graven med en utställning på Konstakademin och med tal av Ulf Linde, som förutom att vara periodens mest kända konstkritiker också var medlem i den Kungliga Akademin för de fria konsterna samt professor i den moderna konstens teori och idéhistoria vid Konsthögskolan. Här avviker tidskriften från den skrattkultur som Bachtin målar upp. PUSS störande av ordningen i det svenska folkhemmet är trots all degradering av makten och etablissemanget en del av en elitistisk kultur och inte primärt en folklig. ${ }^{82}$

\section{Den opassande estetikens och retorikens funktion}

Mot denna bakgrund vill jag avslutningsvis reflektera kring några av smutsens och den groteska kroppens funktioner i det svenska folkhemmet som jag menar synliggörs med hjälp av PUSS, Bachtin och den groteska realismen. I min läsning av PUSS är det tydligt att tidskriftens användning av en groteskt realistisk estetik och retorik med opassande kroppar, kön och sexualitet är centralt för att störa ordningen i det svenska folkhemmet och för att ta plats i det samtida konstnärliga samtalet vid denna tid. Genom att arbeta med den groteska realismens centrala element, den materiellt-kroppsliga principen, hyperbolen och degraderingen, så synliggörs rådande samhällsnormer kring stort och smått, men också hur den dominerande politiska folkhemsvisionen, "att lägga livet tillrätta", är baserad på en i sig tillrättalagd och problematisk version av människan och samhället. ${ }^{83}$ Både därför att enskilda individer kan råka mycket illa ut när det storstädas och läggs tillrätta, ${ }^{84}$ men också därför att vi i dag vet att alla hem, även folkhemmet, består av och med nödvändighet måste bestå av sånt som betraktas som smuts. Det är en fundamental del av vad det innebär att vara människa och leva på jorden. Enligt Mary Douglas är smuts något naturligt som hamnat på fel plats. ${ }^{85}$ Själv skulle jag vilja hävda att den groteska realismen, så som den beskrivs av Bachtin, lär oss att smuts är något naturligt som vi måste leva med, det är en del av livets och kroppens förgänglighet. ${ }^{86}$ Smuts kan vara något naturligt som hamnat på fel plats, men det kan också vara något som inte tas omhand på rätt vis. "Lort-Sverige" blir i detta perspektiv inte något som vare sig kan eller ska byggas, organiseras eller städas bort en gång för alla, utan får i stället en existentiell mening genom att knytas till livets och samhällets fundamentala villkor.

Just därför att PUSS själv definierar sig som en tidskrift som representerar en satirisk antipropaganda synliggör de också den roll som propaganda hade i skapandet av det svenska folkhemmet där livet skulle läggas tillrätta. ${ }^{87}$ Som Jowett \& O'Donnell understryker är propaganda i sig inte något ont, utan en form 
av kommunikation som arbetar aktivt för att påverka oss på ett särskilt vis. ${ }^{88}$ "Propaganda is a form of communication that is different from persuasion because it attempts to achieve a response that furthers the desired intent of the propagandist" ${ }^{89}$ Följaktligen innebär det att där det finns propaganda finns det också anti- eller mot-propaganda, bilder och berättelser som är kritiska till det budskap som propagandan levererar, och oftast också den institution som ligger bakom propagandan, och som på olika vis arbetar för att synliggöra vad som är problematiskt med det hela. ${ }^{90} \mathrm{I}$ ett fritt samhälle kan dessa motberättelser produceras och publiceras öppet och vara en del av det offentliga samtalet, som exempelvis PUSS, medan de i odemokratiska samhällen tvingas röra sig under jord. Därför fyller satirtidskrifter som PUSS, vars grundläggande syfte sägs vara att genom provocerande skratt slå hål på de lögner som bär upp makten i ett samhälle och som väcker ambivalenta känslor genom att överträda olika typer av gränser, också en viktig funktion genom att påminna oss om att vi alltid är omgivna av propaganda.

James Anderson och Amie D Kincaid myntar begreppet "democomedicratic" för att synliggöra den samtida tv-satirens funktion som "somewhat counter-propagandistic and potentially democracy-promoting aspects of mass-mediated satire". ${ }^{91}$ I deras anda skulle jag vilja hävda att satir, som likt PUSS arbetar med en groteskt realistisk estetik och retorik, agerar demogroteskatisk (ett groteskt realistiskt överdrivet begrepp) och därmed har en viktig funktion som en av demokratins gränsvakter. Genom att på olika vis få läsare engagerade (roade, upprörda, medvetandegjorda, kränkta) och därigenom aktivera litteraturens alla olika funktioner sätts offentliga samtal kring centrala frågor och problem igång. Vi tvingas tala om och hantera sånt som vi upplever som svårt, som hotande, som livsavgörande. Det är frågor som alltid är aktuella, men som i dagens nätbaserade och polariserade samhällsklimat fått allt större betydelse. I ett perspektiv har internet medfört att vi lever som i en ständigt pågående karneval. Det vi behöver utveckla är en insikt kring detta baserat på kunskapen att en väsentlig del av det karnevaliska är att det arbetar med ett språk och bilder som betecknas som icke-önskvärda, inte rumsrena, stötande, låga.

Jag vill också argumentera för att det är möjligt att förstå den groteska realismens och det vulgäras kraft just mot bakgrund av vår samtids övergripande strävan efter ett rent, disciplinerat och artigt offentligt samtal och en offentlig sfär enbart befolkad av prydliga och skötsamma kroppar inbegripna i artiga och välargumenterade dialoger - det tillrättalagda svenska folkhem som Hirdman beskriver. ${ }^{92}$ För att tala med Bakhtin är det ett samtal och en sfär som domineras av den klassiska kroppen och inte den groteska. ${ }^{93}$ I ett sådant klimat blir den satir som arbetar gränsöverskridande och med grotesk realism svår att hantera, samtidigt som det är just det faktum att det finns gränser att överskrida som gör att satiren kan fungera överhuvudtaget. Regans analys av Alexander Popes 1700-talsgroteskerier visar att Popes satir fungerar både som en oroande text och som ett vapen med performativ kraft just därför att det finns tydliga regler kring vem som får säga vad och på vilket sätt, och en strävan efter en kultur av "politeness". ${ }^{94}$

I detta perspektiv är det tydligt att PUSS så framgångsrikt kunde störa ordningen i det svenska folkhemmet just därför att det offentliga vid denna tid var präglat av att lägga livet tillrätta på ett respektabelt vis. Genom att låta tidskriftens sidor fyllas av opassande groteska kroppar, genitalier, kroppsvätskor och praktiker synliggjordes effektivt vilken central betydelse kroppen och det kroppsliga, köttsliga, vätskande, fortfarande hade (och har) i det moderna, till synes förnuftsstyrda och rationellt baserade välfärdssamhället. Detta är också något som pandemin gjort världen uppmärksam på igen, vilket innebär att både den groteska kroppen och den groteska realismen inte enbart fătt förnyad aktualitet utan att vi också behöver utveckla nya sätt 
att förstå dess funktioner. ${ }^{95}$ Den opassande retorik och estetik som det groteska förknippas med, påminner oss om att det mänskliga består av kroppar, som inte alltid är vackra, att vi har begär som inte alltid är passande, att demokratiska samhällen består av normer, som hjälper oss att leva tillsammans, men som hela tiden behöver diskuteras och omförhandlas. Dessutom förhoppningsvis medan vi skrattar tillsammans.

\section{Noter}

I Sanna Toren Björling, "'Jag var naiv i början. Den jag var då hade blivit förvånad om hon kunde se var vi fortfarande befinner oss'," Dagens Nyheter, 9 maj 202I.

2 Tack till Gunnar Krantz och Helena Henriksson för värdefull input. Tack också till de två anonyma granskarna vars kommentarer bidragit till att tydliggöra artikeln.

3 Ricki Neuman, Finns det inga gränser: Om satir, massmedier och tryckfrihet (Stockholm: Institutet för mediestudier), 2004.

4 James Anderson \& D. Amie Kincaid, "Media Subservience and Satirical Subversiveness: The Daily Show, The Colbert Report, The Propaganda Model and the Paradox of Parody," Critical Studies in Media Communication 30, $\mathrm{Nr}$ 3, (August 2013), I7I-I88; Michail Bachtin, Rabelais och skrattets historia: François Rabelais verk och den folkliga kulturen under medeltiden och renässansen (Gråbo: Anthropos, I986); Staffan Berglind, \& Karin Ljuslander, Humor som sambällsmoral: Svenskar och invandrare på den Svenska tv-humorns arena (Lund: Studentlitteratur, 1999); Jonna Doona, Political Comedy Engagement: Genre work, political identity and cultural citizenship (diss., Lund University, Faculty of Social Sciences, Department of Communication and Media, 2016); Jonna Doona, "News satire engagement as transgressive space for genre work," International Journal of Cultural Studies 24, Special Issue: Transgression (2020), I5-33; Jonna Doona, "Political Comedy engagement: Identity and community construction," European Journal of Cultural Studies 23 (2020), 53I-547; Anna Lundberg, Allt annat än allvar: Den komiska kvinnliga grotesken i svensk samtida skrattkultur (diss., Linköpings universitet, Göteborg/ Stockholm: Makadam, 2008), se särskilt kapitel I och kapitel 7; Joe Thorogood, "Satire and Geopolitics: Vulgarity, Ambiguity and the

Body Grotesque in South Park," Geopolitics 2I, nr I (2016). 215-235.

5 Robert Darnton, Pornografi och revolution: Förbjudna bästsäljare i det förrevolutionära Frankrike (Stockholm: Ordfront, 1996).

6 Darnton, Pornografi och revolution, 178.

7 Lort-Sverige är titeln på en svensk klassiker där vi får följa Ludvig Nordströms resa genom Sverige där han undersöker landsbygdens bostadsstandard: Ludvig Nordström, LortSverige (Stockholm: Kooperativa förbundets bokförlag, 1938). Nordström var utskickad av Radiotjänst och boken började som en radioserie, "Med Ludvig Nordström på husesyn". Både radioreportagen och boken väckte debatt, både vad gäller de fakta som framkom och det sätt som Nordström valt att skildra människor och deras livssituation på.

8 Martin Åbergs studie av politikern i svensk satir 1950-2000 synliggör just relationen mellan olika typer av gestaltningar av makt och samtida politiska strukturer i samhället. Martin Åberg, Politikern i svensk satir 1950-2000: Från folkhemspamp till välfärdsmanager (Lund: Nordic Academic Press, 20I5).

9 Lars Norén, "Zens, dikt tillägnad Anton Webern", Revolver, Stockholm: Bonnier, 1969, s. 35.

io PUSS, nr I (1968).

II Andreas Berg, "En överjordisk tidning," i Lars Hillersberg: Entreprenör och provokatör, Andreas Berg, red. (Stockholm: Ordfront, 2013), 124-203.

I2 Bang Larsen understryker att PUSS var just ett "estetiskt projekt - både vad gäller visualitet och attityd", se Lars Bang Larsen, "Undergroundtidningen Puss," Hjärnstorm, häfte 92/93 (2007), 73-75. Andreas Berg menar att förklaringen till att Puss "saknar motstycke i svensk publicistisk historia" är "att PUSS från början till slut var ett konstnärligt projekt. Se Berg, "En överjordisk tidning," I30. 
I3 Pelle Andersson, "Satir är det osmakligas konst," i Lars Hillersberg: Entreprenör och provokatör, Andreas Berg, red. (Stockholm: Ordfront, 2013), 6-7.

I4 Kurt Johannesson, Retorik eller konsten att övertyga (Stockholm: Norstedts, 1990).

I5 Roland Barthes,"Rhetorique de l'image," i Oeuvres complètes. Vol. I. I942-I965, Éric Marty, red. (Paris: Seuil, I993), I4I7-I429; Stuart Hall, "The work of representation," i Representation, 2:a utg., Stuart Hall, Jessica Evans \& Sean Nixon, red. (London: Open University/ Sage, 2013), I-59; Annika Olsson, Att ge den andra sidan röst: Rapportboken i Sverige I960-I980 (diss, Uppsala universitet, 2002).

I6 Bachtin, Rabelais och skrattets historia. Bachtin är inte den enda som diskuterat eller teoretiserat det groteska. Andra centrala referenser är Wolfgang Kayser, The grotesque in Art and Literature (Bloomington: Indiana University Press, 1963) och Mary Russo, The Female Grotesque: Risk, Excess and Modernity (New York \& London: Routledge, 1994). För en översikt se Geoffrey Galt Habham, On the Grotesque: Strategies of Contradiction in Art and Literature (Aurora, CO: The Davies Group Publishers, 2006) samt Justin Edwards och Rune Graulund, Grotesque (Abingdon, Oxon: Routledge, 2013). Se även Ingemar Haag, Det groteska: Kroppens språk och språkets kropp i svensk lyrisk modernism (Stockholm: Aiolos, 1999); Per Bäckström, Enhet $i$ mångfalden: Henri Michaux och det groteska (Lund: Ellerström, 2005); Sara Cohen Shabot, "Grotesque Bodies: A Response to Disembodied Cyborgs," Journal of Gender Studies I5, Nr 3 (november 2006), 223-235; Jonas Danielsson, Skräckskönt: Om kärleken till groteska filmer. En etnologisk studie (diss., Umeå universitet, Umeå: H:ström - Text \& kultur, 2006); Lundberg, Allt annat än allvar; Anna Lundberg, "Får vi betyg på det här: Skolflickor, nyliberalism och grotesk komik i samtida svensk ungdomsteater," i Flicktion: Perspektiv på flickan i fiktionen, Eva Söderberg, Mia Österberg \& Bodil Formark, red. (Malmö: Universus Academic Press, 2013), I52-167; Magnus Öhrn, "Med fingret i näsan: Snorets estetik i litteraturen," i Kalejdoskopiska läsningar: Vänbok till Janina Orlov, Maria Andersson et al, red. (Stockholm: Svenska barnboksinstitutets skriftserie I27, 2015), 67-77.
I7 Lundberg, Allt annat än allvar; Cohen Shabot, "Grotesque Bodies"; Thorogood, "Satire and Geopolitics," 22I; jfr Doona, "Political Comedy engagement."

I8 Cohen Shabot, "Grotesque Bodies"; Lundberg, Allt annat än allvar, 269.

I9 Den kritik som riktats mot PUSS har främst rört Lars Hillersberg och antisemitism. Se: Martin Aagård, "Fula grepp av Hillersberg," Aftonbladet, 20 juni, 2013; Andersson, "Satir är det osmakligas konst"; Henrik Bachner, "Kulturhuset slätar över antisemitism," Dagens Nyheter, 24 juni, 20I3; Berg, "En överjordisk tidning; Andreas Berg, "Envis som synden," i Lars Hillersberg: Entreprenör och provokatör, Andreas Berg, red. (Stockholm: Ordfront, 2013), 204-299; Peter Cornell, "Agitator," Expressen, I8 juni, 2013; Mathan Ravid, "Hillersberg på Kulturhuset: Konsten att försvara antisemitisk konst,"Svenska kommittén mot antisemitism: Nyhetsbrev, 20I3; Spektra \& TT, "Skandalös satiriker dyker upp igen," Svenska Dagbladet, I4 juni, 2013.

20 Mitt intresse för PUSS går att jämföra med Joe Thorogoods intresse för South Park, Thorogood, "Satire and Geopolitics", 216.

2I Åke Holmqvist, "Puss - satirisk vänster med stake: tema underground," Hjärnstorm, häfte II5/II6 (20I3), I2-I9.

22 Bang Larsen, "Undergroundtidningen Puss."

23 Kjell Östberg, I968 när allting var $i$ rörelse: Sextiotalsradikaliseringen och de sociala rörelserna (Stockholm: Prisma, 2002), III.

24 Lars Hillersberg \& Åke Holmqvist, Lars Hillersberg: Svenska illustratörer och konstnärer (Stockholm: Orosdi-Back, 2013), 20

25 Hillersberg \&Holmqvist, Lars Hillersberg, I8.

26 Hillersberg \& Holmqvist, Lars Hillersberg, I8-I9

27 Berg, "En överjordisk tidning," I36.

28 Valdemar Gerdin, "Karin Frostenson, Puss och svensk undergroundkultur," i Karin Frostenson. Nutid-dåtid-drömtid: I2 oktober 20I9-26 januari 2020 Thielska Galleriet, red. Patrik Steorn (Stockholm: Thielska Galleriet, 2019), I7-25.

29 Hillersberg \& Holmqvist, Lars Hillersberg, 22.

30 Hjärtat sitter till vänster, Bo A Karlsson, Ulf Kihlander \& Ola Åstrand, red. (Stockholm: Ordfront förlag, I998), 5I.

3I Berg, "En överjordisk tidning"; Hillersberg \& Holmqvist, Lars Hillersberg. 
32 Berg, "En överjordisk tidning," I3O.

33 Olsson, Att ge den andra sidan röst; Östberg, I968 när allting var i rörelse.

34 Östberg, I968 när allting var i rörelse, 69; se även Berg "Envis som synden," 218.

35 Yvonne Hirdman, Att lägga livet tillrätta: Studier i svensk folkhemspolitik (Stockholm: Carlsson, 2000), 90.

36 Hirdman, Att lägga livet tillrätta; Olsson, Att ge den andra sidan röst; Östberg, I968 när allting var i rörelse. Om periodens sexualdebatt, se Lena Lennerhed, Frihet att njuta: Sexualdebatten i Sverige på I I960-talet (Stockholm: Norstedts, 1994); antologin Sex: En politisk historia, Stina Andersson \& Silvia Sjödahl, red. (Stockholm: AlfabetaAnamma/RFSU, 2003); Swedish Cinema and the Sexual Revolution. Critical Essays, Elisabeth Björklund \& Mariah Larsson, red. (Jefferson, NC: McFarland, 2016); Klara Arnberg, "En ohejdad kommersialism: Den pornografiska pressen och regleringen av pornografi i Sverige 1950-2000," Occasional Papers in Economic History, nr I3 (2007); Klara Arnberg, "Synd på export: I960-talets pornografiska press och den svenska synden," Historisk Tidskrift I29, nr 3 (2009), 467-486. En större översikt kring pornografin i Sverige utkommer hösten 202I: Såra tukt och sedlighet: Hundra àr av pornografi i Sverige, Mariah Larsson, Klara Arnberg, Tommy Gustafsson \& Elisabeth Björklund, red. (Stockholm: Natur och kultur, 202I).

37 Som Nylén konstaterar: "Det avantgarde som i mitten av 6o-talet upptas av 'konst $\&$ teknologi' är mot slutet mer nyfiket på 'sex \&politik". Leif Nylén, Den öppna konsten: Happenings, instrumental teater, konkret poesi och andra gränsöverskridningar i det svenska 60-talet (Stockholm: Sveriges Allmänna Konstförening, 1998), I57. Här går det också att göra kopplingar till den funktion som kön, kropp och sexualitet har i den bokhistoriska tradition som Darnton undersöker, likväl som till konsthistorien generellt. Vissa nakna kroppar har varit centrala i konsthistorien, som den feministiska aktivistgruppen Guerilla Girls konstaterar i en av sina klassiska aktioner och affischer 1989: "Do Women have to be naked to get into the Metropolitan Museum". Detta samtidigt som explicita skildringar av sexualitet eller kön ofta ansetts vara opassande.
38 Yvonne Hirdman,"Genussystemet - reflexioner kring kvinnors sociala underordning," Kvinnovetenskaplig Tidskrift, nr 3 (1988), 49-63.

39 Olsson, Att ge den andra sidan röst, 36.

40 Här är det också viktigt att påminna om att PUSS utkommer i kölvattnet av böcker och filmer som Kristina Ahlmark Michaneks brandfackla Jungfrutro och dubbelmoral (1962); Vilgot Sjömans omdiskuterade filmer 49I (1964), Jag är nyfiken: En film i gult (1967) och Bengt Anderbergs tio antologier med erotiska noveller skrivna av så kallade "seriösa" författare: Kärlek (1965-I970) och samtidigt som världens första biofilm med samlag i närbild, den svenskproducerade Kärlekens språk (1969).

4I Nylén, Den öppna konsten, I57.

42 Johannesson, Retorik eller konsten att övertyga, 226.

43 Bachtin, Rabelais och skrattets historia, I2.

44 Berg, "En överjordisk tidning," I30.

45 Hjärtat sitter till vänster, 75 .

46 Victor S. Navasky, The Art of Controversy. Political Cartoons and their Enduring Power (New York: Alfred A. Knopf, 20I3), XIV.

47 För en översikt av synen på och forskning kring tecknade serier i Sverige, se Kristina Arnerud Mejhammar, Självsyn och världsbild i tecknade serier: Visuella livsberättelser av Cecilia Torudd, Ulf Lundkvist, Gunna Grähs och Joakim Pirinen (diss. Uppsala universitet, Strängnäs: Sanatorium förlag, 2020). Forskningen kring just tecknade serier är ett expanderande forskningsfält där det i skrivande stund är flera intressanta publikationer på gång. Se t.ex. "Feminist Comics an Expanding Field," i Comic Art and Feminism in the Baltic Sea Region, Kristy Beers Fägersten et al, red. (London \& New York: Routledge, 202I), I-I4.

48 Till exempel Temi Odumosu, Africans in English Caricature 1760-I8Ig: Black Jokes White Humour (London: Harvey Miller Publishers, 20I7).

49 I boken Barn - serier - sambälle (1954) argumenterar Nils Bejerot, inspirerad av den amerikanska förlagan, Fredric Werthams Seduction of the Inncocent (1954), för att genren krävde någon form av reglering på grund av dess opassande innehåll. Se Mejhammar, Självsyn och världsbild i tecknade serier, 32-34. 50 Bang Larsen, "Undergroundtidningen Puss," 75 . 
5I Bengt Olvång, Våga se! Svensk konst 1945-1980 (Stockholm: Författarförlaget, I983), I05.

52 Johannesson, Retorik eller konsten att övertyga, 229.

53 Bachtin, Rabelais och skrattets historia, 28-29.

54 Haag, Det groteska, I4.

55 Bachtin, Rabelais och skrattets historia, 29.

56 Thorogood, "Satire and Geopolitics," 230.

57 Bachtin, Rabelais och skrattets historia, 3I.

58 Jfr Haag, Det groteska, 57.

59 Bachtin, Rabelais och skrattets historia, 26.

60 Bachtin, Rabelais och skrattets historia, 26-27.

6I "Puss", i Nationalencyklopedin, https://wwwne-se.proxy.mau.se/uppslagsverk/ordbok/ svensk/puss

62 Karin Frostensons konstnärskap lyfts fram i katalogen Karin Frostenson. Nutid - dåtid - drömtid: 12 oktober 2019 - 26 januari 2020 Thielska Galleriet, red. Patrik Steorn (Stockholm: Thielska Galleriet, 2019).

63 Jfr Göran Palm, Indoktrineringen i Sverige (Stockholm: Norstedts, 1968).

64 Erlander förekommer för övrigt även i senare nummer, iförd långkalsonger med stjärnbaneret på ytterligare en bild där han tillsammans med Geijer avbildas av Lena Svedberg som "CIAmesiska tvillingar", se PUSS, nr 6 (I968).

65 Holmqvist, "Puss - satirisk vänster med stake: tema underground". Denna bild förekommer också i Öyvind Fahlströms film Du gamla, du fria (1972) som spelades in 1969 och som bygger på olika typer av vad man skulle kunna kalla för groteskt realistiska provokationer. PUSS var involverad på olika vis i detta projekt, bland annat under den vattendemonstration man anordnade på svenska flaggans dag och där bilden förekom på ett segel.

66 PUSS, nr 3, (I968); Berg, "En överjordisk tidning," I30.

67 Bang Larsen, "Undergroundtidningen Puss."

68 Ira Mallik, "Porr som vapen," i Sex en politisk historia, Stina Andersson och Silvia Sjödahl, red. (Stockholm: AlfabetaAnamma/RFSU, 2003), I49-155.

69 Bachtin, Rabelais och skrattets historia, 3I.

70 Thorogood, "Satire and Geopolitics," 223.

7i PUSS, nr io (1968).

72 PUSS, nr I5 (1970).

73 Om Lena Svedbergs konst se Lena Svedberg \& Carl Johan De Geer, Lena Svedberg (Stockholm: Orosdi-Back 20II).
74 Rita Felski, Uses of Literature (Malden, MA \& Oxford: Blackwell Publishing, 2008).

75 Alistair Fowler, Kinds of Literature: An Introduction to the Theory of Genres and Modes (Oxford: Clarendon Press, 1982).

76 Bachtin, Rabelais och skrattets historia, I6-I7.

77 Bachtin, Rabelais och skrattets historia, 19.

78 Fowler, Kinds of Literature. Se även Doona, Political Comedy Engagement; Doona, "News satire engagement as transgressive space for genre work”. Här går det också att jämföra med den analys Danielsson gör i sin avhandling där han analyserar skräckfilmstittare med hjälp av Bachtin (Danielsson, Skräckskönt).

79 Felski, Uses of Literature, I5.

80 Bachtin, Rabelais och skrattets historia, 22.

8I Pierre Bourdieu, Distinction: A Social Critique of the Judgement of Taste (London \& New York: Routledge, 20IO).

82 Mot denna bakgrund går det också att hävda att den stör ordningen i det karnevaliska rummet, och att tidskriften representerar ett traditionellt avant-gardistiskt vis att både ta plats på och agera. Denna aspekt är dock inte något det finns utrymme för att vidareutveckla i denna artikel.

83 Här är det också möjligt att relatera till Michel Foucaults beskrivningar av makten och byråkratin som grotesk, se Edwards och Graulund, Grotesque, 26-32.

84 Idag vet vi att den svenska folkhemshistorien rymmer flera exempel på detta. Några exempel på det som belyser problematiken är studierna kring svenska steriliseringslagar, medicinska experiment (Vipeholm) och dagens omfattande diskussion kring internationella adoptioner. Se Gunnar Broberg \& Mattias Thydén, Oönskade i folkhemmet: Rashygien och sterilisering $i$ folkhemmet (Stockholm: Gidlund, I99I); Röster från Vipeholm, Cecilia Carlén-Nilsson \& Ulla Holmér, red. (Lund: Stiftelsen Medicinhistoriska muséerna i Lund och Helsingborg, 1998) samt Elin Bommenel, Sockerförsöket: Kariesexperimenten 1943-1960 på Vipeholms sjukhus for sinnesslöa (diss., Lunds universitet, Lund: Arkiv, 2006); Tobias Hübinette, Adopterad: En bok om Sveriges sista rasdebatt (Stockholm: Verbal, 2020).

85 Mary Douglas, Renhet och fara: En analys av begreppen orenande och tabu (Nora: Nya Doxa, 20II). Maria Margareta Österholm menar att 
synen på smuts och synen på monster i det västerländska samhället går att koppla ihop. De skapar oreda i ordningen. Maria Margareta Österholm, Ett flicklaboratorium i valda bitar: Skeva flickor i svenskspråkig prosa från I980 till 2005 (diss., Uppsala universitet, Stockholm: Rosenlarvs förlag, 2012), I87-I94.

86 Här intar jag en hållning i relation till smuts som går att jämföra med de tankar Fanny Ambjörnsson lyfter kring städning som praktik. Hon argumenterar för att städning är så negativt laddat eftersom det påminner oss om alltings förgänglighet. Fanny Ambjörnsson, Tid att städa: Om vardagsstädningens praktik och politik (Stockholm: Ordfront, 20I8), $2 \mathrm{I} 4$.

87 Hirdman, Att lägga livet tillrätta. Se även Jimmy Vulovic, Propaganda. Historia, teori och analys (Lund: Studentlitteratur, 2017); Efterkrigstidens sambällskontakter, Fredrik Norén \& Emil Stjernholm, red. (Lund: Mediehistoriskt arkiv, 20I9).

88 Garth S. Jowett \& Victoria O’Donnell, Propaganda and Persuasion, 2:a utg. (Newbury Park,

\section{Summary}

Grotesque bodies in the Swedish folkhem: Improper aesthetic and rhetoric in the magazine PUSS I968-I974

In an analysis of the Swedish satirical magazine PUSS (1968-1974) this article explores what is considered as improper rhetoric and aesthetic in the public sphere. It draws on theories of representation and the culture of carnival laughter and the grotesque as well as research on the Swedish folkhem and satire and democracies. I coin the concept demogrotesque-atic in order to capture how PUSS, by using comics, grotesque bodies and carnivalesque, improper rhetoric and aesthet-

ics, makes visible fundamental challenges to democratic societies. I argue that the magazine's representational practices highlight the function of what is often considered 'filth' in the public sphere and the central role the grotesque body plays in upholding - and breaking - boundaries of propriety. I interpret this as important democratic work, and demonstrate that while the satire in PUSS is situated in a specific time and place, it is also part of a longstanding literary and artistic tradition.

Keywords: PUSS, political satire, grotesque bodies, Bachtin, representation, Swedish folkhem, democratic work, demogrotesque-atic 